\title{
Libertarian Populism, Neoliberal RATIONALITY, AND THE MANDATORY LONG-FORM CENSUS: IMPLICATIONS FOR SocIOLOGY ${ }^{1}$
}

\author{
WiLLIAM RAMP \\ TREVOR W. HARRISON
}

\begin{abstract}
This article argues the Canadian government's decision in 2010 to eliminate the mandatory long-form census constitutes a mobilizing appeal to libertarian populism commensurate not only with neoliberal concepts of individualism, private property, and the role of the state, but also with a redefinition of what counts as valid argumentation and a legitimate basis for making knowledge claims. This rationale has implications for sociological research and theory, for the profession of sociology, and for a sociological vision of society.
\end{abstract}

Key words: populism; governmentality; individualism; state; property; privacy

Résumé: En 2010, le gouvernement du Canada décide d'éliminer le formulaire long obligatoire du recensement. Notre article soutient que cette mesure constitue un appel sans équivoque à la mobilisation du populisme libertarien conformément aux concepts néolibéraux de l'individualisme et de la propriété privée et à une conception particulière du rôle de l'État. Nous démontrons également que pareille initiative entraine la redéfinition de ce qui représente une argumentation valable et une base légitime pour cerner les questions portant sur la connaissance. En fin de compte, cette logique a des conséquences sur la recherche et sur la théorie en sociologie, sur la pratique de la sociologie elle-même et sur une vision sociologique de la société.

Mots clés: populisme; gouvernementalité; individualisme; état; propriété; vie privée

1. The authors wish to thank the anonymous reviewers for their very helpful comments.

(C) Canadian Journal of Sociology/Cahiers canadiens de sociologie 37(3) 2012273 


\section{INTRODUCTION}

D) y an Order in Council on June 17, 2010, federal Minister of IndusD try Tony Clement, replaced Canada's mandatory long-form census (MLFC) used since 1971 with a voluntary National Household Survey. The decision quickly drew criticism from many quarters, including some provincial governments, academic institutions and associations, voluntary organizations and churches, business, and professions. ${ }^{2}$ In response, Minister Clement over the next several weeks provided several explanations for the decision. Most critics remained unpersuaded, arguing that the decision was constitutionally problematic and methodologically unsound (Thompson 2010; Veall 2010; Dillon 2010; Green and Milligan 2010). By implication, the government's decision appeared illogical, even irrational, to such critics.

The critics are correct with respect to the constitutional and methodological issues. Certainly, many of the reasons given for ending the MLFC appear contrived and unsupported by evidence. Likewise, we generally concur with those who have described the Conservative government's decision as reflecting an ideological (libertarian) bent (Simpson 2010; Potter 2010a).

However, we argue that the government's decision was in fact marked by a particular, if tendentious, logic. We situate the decision within an appeal informed by libertarian populism and grounded in the rationale of neoliberal ideology. Instead of arguing the public interest in maintaining the MLFC, as some critics have done, we explore how the government's appeals to its supporters mobilize neoliberal concepts of privacy and private property, individualism, and the role of the state. These concepts are organized into particular narratives about democracy, fairness, rights and agency, and the prerogatives (legitimate or otherwise) of taxpayers, interest groups, and state agencies. We further suggest that the government's actions evidence both a "retreat from governance," in H.T. Wilson's prescient term (1989), and an implementation of governance (broadly conceived) in other ways and by other means. To understand this mode of governance, and its implications for sociology, we must first rethink the concept of populism as involving not only a particular type of political imaginary, but also a culture and, as Saurette and Gunster (2011) argue, a communicative strategy and a discourse of self and social position, of experience, of rights, and of the validity of knowledge.

2. By contrast, prominent organizations supporting the government's decision could be counted on one hand - the Fraser Institute, the National Citizens Coalition, and the Canadian Taxpayers Federation - along with the provincial governments of Alberta, British Columbia, and Saskatchewan. 


\section{Libertarian Populism Versus the Mandatory Long-form Census}

In the weeks following his decision, Minister Clement and other Conservative MPs offered several justifications for cancelling the MLFC. Clement stated that Statistics Canada supported the decision and that the agency concurred that statistical information gathered through voluntary means would remain reliable and comparable with past censuses. Critics quickly panned Clement's defense, scolding the minister for an apparent misunderstanding of sampling methods and tests for reliability. His claim was formally and fatally refuted on July 21 by Statistics Canada's chief statistician, Dr. Munir Sheikh, on the occasion of his very public resignation from the post: "I want to take this opportunity to comment on a technical statistical issue which has become the subject of media discussion ... the question of whether a voluntary survey can become a substitute for a mandatory census. It cannot" (statement quoted in Chase and Grant 2010).

Shorn of a school of red herrings, the government's primary justification for eliminating the MLFC appeared from the start to rest upon libertarian arguments, specifically a defense of individual privacy against alleged intrusions by the state (see Thompson 2010); arguments similar to those the same government employed against the mandatory long-gun registry. The Prime Minister's Office stated that " $[\mathrm{t}]$ he government made this decision because we do not believe Canadians should be forced, under threat of fines, jail, or both, to disclose extensive private and personal information" (quoted in Valpy 2010). Minister Clement contended that "the government of Canada had received complaints about the longform census from citizens who felt it was an intrusion of their privacy" (Lethbridge Herald 2010), an explanation echoed by fellow Conservative Maxime Bernier, who cited "thousands" of complaints he had received about the census while industry minister (Proudfoot 2010a). Clement argued that the census was "heavy-handed," implying further that the MLFC was an example of "state coercion" and government intrusion (see Potter 2010a). These justifications were soon accompanied by assertions that many Canadians had complained of feeling coerced by threats of fines and jail terms if they did not complete the MLFC.

Again, skeptics questioned the evidence for such arguments, asking how many complaints had actually been received and over what period. On July 14, the federal privacy commissioner stated that she had not been consulted or briefed regarding the decision to end the MLFC; that her office had only received two complaints about the previous 2006 census; and that over twenty years, her office had received a mere fifty complaints, only some of which were about the MLFC (Lethbridge 
Herald 2010). Further investigations showed that no one had ever been jailed for refusing to answer its questions. In short, government statements that the MLFC had been employed coercively were unsupported by evidence. Moreover, a recommendation by the 40 member National Statistics Council, which advises Statistics Canada's chief statistician, that the Statistics Act be rewritten to remove any threat of jail was ignored (Proudfoot 2010b).

Without evidence of actual or threatened punishments, the government might have defended its decision on purely libertarian grounds; that the state had no right ever to require individuals to provide information. But this justification would have failed the test of the government's own subsequent actions; in particular, its insistence that both the 2011 Census of Agriculture and the short-form census would remain mandatory. Clearly, libertarian arguments were not entirely sacrosanct, as noted by several critics (Cosh 2010; Coyne 2010; Gardner 2010). ${ }^{3}$ How, then, might we understand the decision, stubbornly maintained, to end the MLFC? How do libertarian arguments square with the necessities of governance? How and why were they deployed, despite apparent limitations and contradictions, and what are their implications for political mobilization and the changing role of the state? To address these questions, it is useful first to examine the conjunction of libertarianism and populism and its place within modern Canadian conservatism.

\section{The Rise of Libertarian Populism}

Populism was not always central to Canada's conservative tradition (Noel 1990). John Diefenbaker's Progressive Conservatives rode a western populist wave to power in the late 1950s: that victory, though short lived, signaled a longer decline of traditional Toryism (Grant 1965), and an eventual fracturing of the Progressive Conservative party. Though briefly reversed during the administration of Brian Mulroney, this fracturing recurred in 1993 at the hands of the Bloc Quebecois in Quebec and the Reform Party in western Canada (Harrison 1995; Flanagan 2009a). The latest period, beginning in 2004, saw the Reform Party cum Canadian Alliance merge with and then subsume the remains of the former Progressive Conservatives, in an entity renamed - sans Progressive - the Conservative Party of Canada, led by Stephen Harper (see Flanagan 2009b).

3. Gardner noted that the government's libertarian stance seemed to end at the idea of decriminalizing marijuana or revoking laws regarding selling sex for money. 
Central to the Conservative party's transformation was its adoption of populism both as a symbolic end and as a rhetorical device. Preston Manning's founding of the Reform Party in 1987 specifically adopted traditional populist imagery - "the common sense of the common people" - in opposition to elites and "special interests," and symbolically grounded it in a series of historical antecedents (e.g., various farmers' parties, Social Credit, the Cooperative Commonwealth Federation) (Manning 1992).

Today, however, even many of the Conservative party's staunchest supporters concede it has strayed far from its recent populist roots. Gone are the Reform party's dreams of direct democracy referenda, voter initiatives, and recall; only the shibboleth of Senate reform remains. The Conservative government of Stephen Harper does not constitute the political expression of a mass movement per se: though playing to a hardright voting and activist base, its communications are tightly controlled, with a sort of reverse-direction populism in which polling-derived "popular will" statements are delivered to supporters. There seem few formal entry points for regular citizens to press their interests (Martin 2011).

Yet the term "populism" is still useful if applied somewhat differently to include the Conservative government's particular use of rhetoric, and its way of formulating policy messages to invoke a particular kind of political subjectivity with strongly populist characteristics. Its charged references to an anti-elitist common sense, and to property and privacy rights of ordinary individuals, are forms of sense-making which construct a broad social imaginary; a sort of moral geography in which agents and objects can be articulated and mobilized. Thus, we suggest extending the term "populism" to cover specific modes of discursive organization and characteristic rhetorical gestures through which social agents (parties, governments, officials, professionals, taxpayers) are identified and construed in particular ways, often as stock figures. While the Conservative Party may no longer be populist in organizational practice, it engages in characteristic forms of populist mobilization (Jansen 2011), linking selected popular aspirations, fears, or resentments to elements of populist political discourse and rhetoric, and "operationalizing" the result in specific communicative strategies by which (credible or discredited) agents are identified, events interpreted, and actions or policies justified and promoted.

The decision to cancel the MLFC was buttressed by generalized public skepticism towards institutions, especially government. The Conservative government's embrace of populism inoculated it against similar skepticism by allowing it to present itself as defending the people 
against elites; in this sense, Yalnizyan's (2010), characterization of it as an "antigovernment" government was apt.

The government pitted itself in the census issue against one specifically identified "elite," the intellectual class: a grouping said to be defined by its use of obscurantist terminology and general disengagement from the lay public. The MLFC's characterization by representatives of the Fraser Institute (Veldhuis and Lamman 2010) as "a cheap way for academics and social scientists to get information that ... should be acquired using voluntary means" was meant to specifically target academic opposition to the cancellation as the bleating of a special interest group seeking a privileged deal. At best, academics were viewed as out of touch; at worst, as charlatans and hoaxsters whose "knowledge" - the basis of their claims to status, expertise, and taxpayer-funded resources - was bogus.

One could dismiss such representations merely as additional examples of a resentful anti-intellectualism long, if debatably, associated with populism (Hofstadter 1966; but see Ramp and Badgley 2009:26$35)$. However, while contemporary right-wing populism encourages varying degrees of skepticism about intellectuals and their knowledgeclaims, it also underwrites a more radical challenge to the grounds of observational knowledge itself, undermining a key element of the Enlightenment project while embracing its anti-authoritarian spirit. Such skepticism can even co-opt the language of postmodernism, but it tends to serve a different, more visceral certainty, as explained below.

Kay (2011) suggests, counter-intuitively, that these developments accompany rising levels of formal education, ${ }^{4}$ and are fed by secular relativism in the academy and a postmodern rejection of monolithic canons and their defenders. Wilson (1977:ch. 2) presaged a somewhat different hypothesis: that an instrumentalist "science-based" model of rationality combined with professional and bureaucratic specialization restricted 20th century North Americans' sense of what knowledge and reason could entail. This technocratic model promised progress and opportunity, but encouraged economic, technological, and social-policy initiatives which destabilized local and communitarian supports, threatened stability of employment, and undermined the grounded knowledge and agency of ordinary people. A wounded skepticism of scientific, bureaucratic, and technical authority, selectively combined in popular discourse with a certain anti-authoritarian relativism, thus becomes available for mobilization on issues from vaccination to climate change. We suggest that it also informs a central figure and a remaining focus of certainty in

4. Of OECD countries, Canada has the highest percentage of postsecondary graduates in the 25-64 age range (Boothby and Drewes 2010). 
libertarian populism: the self-sovereign individual who refuses to defer to established elites.

Sovereign individuals are deemed to have certain inherent and absolute rights, subject to no higher authority other than one they freely accept, and restricted only by a requirement not to cause direct harm to the person, property, or integrity of another. Among this individual's unassailable rights is the right to judge and to espouse facts as one sees them. This right can be linked to a capacity to engage in civic conversation. But in populist political communication and popular journalism, the sovereign individual is reduced to a particular kind of rhetorical trope; no longer a conversationally engaged homo civicus but a generic yet singular "ordinary Joe" who knows what he knows. Concomitantly, the right to judge and to speak shifts from the context of civic participation to that of individualized personal experience, perceptions, and opinions; indeed, assertion of the right requires no other basis. Others may see an individual's expressed views as ridiculous, but the speaker is under no obligation either to test or defend them or to restrain their expression. The American politician Daniel Patrick Moynihan famously remarked that, "Everyone is entitled to his own opinion, but not to his own facts." By contrast, libertarian populists can and do on occasion proudly assert a right to hold and to judge "facts" as they like; as they see or experience them.

Saurette (2010) calls this outlook "epistemological populism," an orientation to knowledge which privileges the reliability of ordinary individuals' direct opinions and personal experiences (the lessons of which can be generalized unproblematically) over the perceived abstractions generated by social science research. "In such a theory," notes Saurette (2010), "the more numerical, general, and statistical the analysis, the less trustworthy it is." Thus, emphasizing the objective evidentiary value of the MLFC could actually feed a sentiment in favour of its elimination (on this, see also Dillon 2010); or, to broaden the point, statistical evidence of global warming, or of the safety of vaccines, or of a decline in criminal activity, could actually incite suspicion of all three. In a thoroughgoing epistemological populism, one begins and ends with one's own experience and with taken-for-granted generalizations which frame the world in a narcissistic and moralized way not open to critical dialogue, qualification, or self-reflection, insulated instead by association with like-minded sovereign individuals, united by suspicion of professional or institutional knowledge production.

The practice of this sort of libertarian populism finds its apogee in talk radio, a medium dominated in the United States and Canada by right-wing hosts. The discursive organization of talk radio involves what Saurette and Gunster (2011) term "argutainment," a form of political 
messaging that melds the rhetoric of advertising and entertainment with that of public relations to produce bellicose statements which are short, punchy, and emotionally laden, and which privilege assertion of a supposed common self-experience. In the promotional culture (Wernick 1991) that provides its context, other forms of communication acquire a negative moral evaluation. Academics, for example, are attacked (and sometimes attack themselves) for using convoluted language, but the issue goes beyond this. Academic language in the social sciences is typically nuanced and self-qualifying, carefully employed to build a case. From the epistemological standpoint of talk-radio populism, such language appears obscurantist and weak, and therefore suspect and untruthful: by extension, its users are deemed undeserving of a platform. By contrast, unequivocal points-with-a-punch draw attention and emotive identification. But because they "come from the heart" of an archetypal ordinary individual, such statements carry a self-legitimating weight and convey privileged access to "common sense." The key element here is a libertarian emphasis on the inherent moral and cognitive qualities of ordinary individuals, reflective of the distinctly antitechnocratic nature of contemporary populist skepticism (Saurette 2011:213). In the radically egalitarian and individualistic universe inhabited by libertarian populists, commoners and elites alike might have rights - as comedian Stephen Colbert might say — to their respective "truthiness," but the truth-claims of elites are discredited by their social positions, attitudes toward personal experience, and communicative strategies.

A libertarian epistemological populism offers particular discursive resources for constructing protest narratives which pit ordinary people against power-hungry elites, oppressive institutions, and a baffling language of abstractions. Rhetorical contrasts using labels like "nanny state," "elites," and "the bureaucrats" were deployed to galvanize core supporters in relation to the census decision, accentuating what Jeffrey Simpson (2010) called “the Conservatives' oft-displayed disregard, even contempt, for 'expert' information and analysis." The Conservative government's cancellation of the MLFC appealed both to a libertarian skepticism about claims making by academic elites, and to a popular faith in the knowledge value of personal opinion and experience. In the face of this linkage, arguments by academics and other professionals against the decision to drop the MLFC were doomed to fall on deaf ears.

One might explain the decision to scrap the MLFC as a political mobilization tactic, targeting a particular voter base through an appeal to libertarian populism. But the census decision and its justifications can also be read as a particular communicative strategy; a ritual condensation (Fiske and Hartley 1978:89-91) of complex issues to elicit emotional re- 
sponses similar to those enjoined by talk radio. To more fully understand this appeal, it is useful to situate libertarian populism within the broader tenets of neoliberal ideology, especially its construction of the individual, and of individual rights and capabilities, in relation to public life or public goods; and more specifically, right-wing populist interpretations of the "common man" and the role of the neoliberal state in representing "his" interests.

\section{The Common Man - and the Absent Commons - in Neoliberal Discourse}

We argue that the decision to end the MLFC must be understood, in part, as a battle over the discursive construction of personal sovereignty and the nature and value of knowledge. But this battle also involves a narrative reconstruction of the common: what interests, rights, and social goods citizens hold in common; what constitutes common sense; how the "common" may be counter-posed to that which lies outside it, and how the common relates to the concept of the individual. These narratives are more than window dressing for anterior material interests. They have their own discursive importance, making it possible (or impossible) for certain things to be said, and for certain things to be meaningfully done. What is at stake here, inter alia, is a politics of voice; not only "who is allowed to speak," but what they may legitimately say, who they become as agents when they say it, and what sort of responsive identity "hearing" them entails. This narrative politics is a key element in the history of a populist discourse of government, sovereignty, truth, and rights; itself part of the history of cultural projects to redefine the modern nation state (Corrigan and Sayer 1985), and perhaps also to reinvent Canada and Canadians.

A brief tour of the ideological contours of neoliberalism, arguably the dominant ideological discourse of our age, is useful here. ${ }^{5}$ Rather than focusing on neoliberalism's high theoretical apostles, or on neoliberal economic policies - free trade, privatization, deregulation - we consider instead the notion of the individual that popular neoliberalism calls into being, and the manner in which political appeals are made to it. The transformation of political conservatism in Canada, like its British and American antecedents, involved shaping, packaging, and selling social and political policy in terms of appeals to the common person, or the common sense of ordinary people, in opposition to a kind of changeling elite - an appeal and a style of politics we identify as populist.

5. On the broader history of neoliberalism, see Harvey 2005; Mirowski and Plehwe 2009. 
Historically, both right and left populist movements drew on powerful political narratives in which images of "the people," the "common good," and "the individual" commingled, often uneasily. This might seem surprising, given right-wing populism's current reputation for being libertarian and individualist, but in the past it has incorporated communalist references to race, religion, locality, or nation. Left-populism, conversely, privileged a collective sense of the "common good," promoted natural or civic communities, and occasionally advocated nationalization, but also supported cooperativist iterations of individual initiative and property-holding.

As far back as 17th century "commonwealth" republicanism, veneration of the common person was often nested within representations of a collective commonalty (see Rollison 2006, 2010; Scott 2004), and shaped by an emphasis on groups, activities, and relationships. These survived in claims about the "dignity" of agriculture or labour, in advocacy of natural communities of producers, or in claims about organic connections of common persons to the tools, materials, and products of their work. They were still evident in the "producerism" (Palmer 1979), championed by early 20th century craft unionists and agrarians, which represented patronage appointees and financial speculators alike as parasitical elites, living on "rent" generated by true wealth producers: farmers, workers, and small entrepreneurs. Twentieth-century agrarian progressive proposals for "group government" represented different types of producers, along with consumers, as forming communities that could engage with each other in cooperative trade and civic action. Images of relationality and pride in work persisted even in neoliberal rhetoric, which contrasted hard-working entrepreneurs to rent seekers, and free trade to dependence or patronage.

However, in contemporary neoliberal populism, the balance, uneasy or otherwise, between individual and social is all but lost; the concentration on relationships or activities displaced by absolutized property rights of the individual self. The "common man" (or woman) owes little to the social; the collective aspect of the "commons" has little meaningful referent beyond the idea of a numerical assemblage of majority opinion, and "common sense" is not represented as a collective product. The notion of the "common" (or "public") interest is viewed negatively as hiding the false self-interests of elites, or positively as an assembled expression of the true self-interests of private individuals who exist always outside the "commons," alone, but in the Lockean sense, sovereign.

Possessive individualism has deep historical roots (Macpherson 1962), but its contemporary forms relate more to consumer property rights than a 17th century yeoman ethic or a Jacksonian entrepreneurial 
ethos. In its current iteration, the customer is king twice over; by virtue of possessing money with which to purchase (or refuse) what is on offer, and by virtue of an unchallengeable right to exercise judgment in a world of goods and services. A cultural extension of this right to judge treats holding or voicing opinions as analogous to property rights; less a right to enter civic dialogue than to possess and declare one's opinions as one wills.

Two key drivers of 20th century Fordism, the advent of the modern information state, ${ }^{6}$ and of a generic consumer economy cleansed of "backward" communal elements (Ewen 1976), thus gave populism new things to fear, but also new forms and modes of expression, including a rearticulation of common persons not only as "productive" but as having consumer rights to be defended. Thus, general taxation, a necessary and increasingly visible underpinning of the Fordist state, could be represented as taking "hard-earned" wealth from ordinary people, but also as limiting private enjoyment of consumer wealth. To the extent that the modern state requires collection of information as well as taxes, information gathering, too, could be represented as unjustified and unearned appropriation, though the case that it restricts private enjoyment is perhaps less self-evident. The idea of "the customer as king" also, over time, came to be applied to political evaluations of the services - including information services - offered by the Fordist state and its agencies.

This shift was abetted by massive technological revolutions in production, and the development of a globalized labour market, undercutting the idea that the common knowledge or wisdom of ordinary folk resided in their shared productive capacities (e.g., Crawford 2009). The rationalization of labour processes involved expropriation of producergenerated work knowledge, and its replacement with automated technologies and "expert systems," weakening producers' shared sense of control over, or pride in, their work. Consequently, defensive popular definitions of commonsense knowledge have begun to privilege individual knowledge of wants and expectations, now in relation to the purchase and consumption of goods and services for private life. But like production, consumption has also undergone a sort of managerial deskilling ("no owner serviceable parts inside!"), rendering it formulaic and frustrating (Steigler 2010). The frustration of local knowledge and

6. A state system invested in knowledge and communications infrastructures, and in the production, storage, and dissemination of information, for sovereignty and security, and to manage populations and productivity. The introduction of the standard decennial census using interpretive schemata based on abstract categories, and the inductive and probabilistic analysis of statistical data, were central to its development. See, e.g., Curtis 2001, 2002; Foucault 2007; Hacking 1990; Desrosiers 1991; Poovey 1998; Coven 2003. 
agency in both production and consumption arguably destabilizes not only forms of community but also forms of self, engendering both fears and resentments (Sennett 2006) which, when provided with specific targets, could transmute into focused anger and contempt.

While these developments are driven largely by a rearticulation of global capitalism (including redefinitions of labour and property rights), the right-populist narrative assertion that the main culprit in the restriction of consumer rights and enjoyment is government, has had remarkable success, partly due to successful rebranding of transformations in capitalist production and distribution as a moral and material good for individual consumers, rather than a social harm or moral hazard. If a commercial organization cannot continue to attract "votes" in the form of dollars freely offered, the argument goes, it has no right to patronage; indeed, no right to exist. By extension, this transmutes into a justification for neoliberal resistance to state intervention in the economy; to state provision of goods and services; to state "monopolies" in areas such as education and health care, and ultimately, to "mandatory" state interventions in private life or business that do not derive from some specific and freely expressed majority preference. ${ }^{7}$

The consumerization of political rights develops in tandem with a consumerization of politics itself, evident in political entrepreneurialism, promise inflation, and the promotion of political messages involving stock imagery and emotional appeal. Such developments are both products of and contributors to a chronic legitimation crisis of the state (Habermas (1975, 1989; see also Wilson 2002:253-272). Rather than a Fordist institutional-technocratic domination of the life-worlds of ordinary voters, they involve a perilous cultivation of hybridized citizen/consumers under the "philosophical banner of market utopianism" (Saurette and Gunster 2011:215). "Retail politics" thrives on identifying, articulating, and promoting popular fears and antipathies which are turned to particular account by condensing issues to fit mythic narratives populated by typecast figures (persons, groups, or interests) represented as enemies of freedom, productivity, fairness, or common sense, however tendentiously defined. To a certain degree, Stephen Harper's open preference for ideological polarization in Canadian politics between left and

7. When citizens become "taxpayers" whose personal interests, numerically added up, constitute "majority opinion" used to legitimate or delegitimate tax expenditures, a civic element is lost. Instead of elected assemblies debating civic priorities, tying taxation to representation now means encouraging individual taxpayers or "stakeholders" to demand accountability in terms of private interests in adequate returns in tax-funded goods and services. Taxation becomes less civic duty than commercial transaction: taxpayers become sovereign customer-judges of publicly supplied goods and services bought with "their" tax dollars, and tax reform a matter of "putting our money back in our pockets." 
right, with no liberal middle, reflects this, as did the style of campaign recently favoured by the federal NDP. Also at work here is a style of communication that melds advertising, entertainment, and public relations (as in talk radio, already discussed) in which message saleability depends on the immediacy of impact and ease of consumption. The style and content of such communication also fits an individualization or "cocooning" (Bijsterveld 2010) of privatized acoustic space, as in car radio listenership.

Critics who note only the damage done to the arms length professionalism of the federal civil service and of regulatory agencies by the Conservative government's reconfiguration of the state in line with a partisan embrace of right-populist discourse miss a key point: the "public" nature of the state, from the right-populist perspective, does not mean independence from party politics, but actually the opposite. Inasmuch as the party in power is imagined to most directly represent "me," an individualized, commonsensical ordinary taxpayer, who, in aggregate with others "like me," is the "real" employer and owner of the machinery of state, that party can also claim entitlement to deal with "my" employees and "my" assets, which it manages on "my" behalf, as it wishes. While the mediation implied by "on my behalf" retains some potential for discomfiture, this is compensated for by a rhetoric of commonsense affinity, intimating a direct channel to what is being said and thought in family rooms, in coffee shops, and on talk radio across the nation about the rightful scope of government. But a right-populist government must also be seen to be accountable to its public in ways that involve rhetorical action as well as rhetorical speech. The axing of the MLFC was a symbolic act, removing a governmental function that, whether or not it actually was an imposition, could be represented as something that should be seen as one, and about which "your" government was prepared to do something.

In this outlook, "common sense" is not a collective product; nor does the "common man" (or woman) derive knowledge from social engagement, except through exchanges used (somewhat mysteriously) to assemble a collection of ideas and make personal choices. Neoliberal individuals are self-owning and sovereign in spaces marked off from a "commons" as their private domain, from which they may make public statements and claims, but which they never quite leave. In contemporary popular imaginaries generated by political mobilization strategies or talk radio venting, this manifests in a singular, solitary sovereignty rather than a civic one informed by Smithian moral sentiments. It is also, in practice, the bare sovereignty of a deskilled electoral consumer on whose behalf individual emotional response, personal opinion, and personal experience, are proclaimed as ultimate criteria of valid truth claims, even as 
actual individuals' experiences and responses are harvested and remanufactured in packaged form by sophisticated communications agencies, as off-the-shelf goods available for buy-in.

It is important not to confuse the archetypal individual of this populist neoliberal imaginary with actual individuals who subscribe to neoliberal causes. The latter bring to their engagement with parties, movements and media a range of moral positions and perceptions. Many are active in volunteer work and philanthropy; feel a sense of community responsibility; even value certain government services (see, e.g., Williamson et al. 2010). Many who are conservative Christians would refuse in principle to subscribe to an absolutized individual self-sovereignty in making either knowledge claims or political and economic decisions. Most use or refer to some forms of expert knowledge even while decrying others. And, to repeat, neoliberals and federal Conservatives are not the only employers of populist political mobilization strategies; they are merely the least constrained and most effective at what has become a common, though not universally accepted, feature of political and journalistic culture.

That being said, the active and partisan promotion of the sort of neoliberal populism we have outlined does not well equip its recruits with tools for discernment, nor encourage thinking through possible contradictions in the ideological or narrative structure of mobilizing messages. James Travers (2010) suggested that, by pandering to conspiratorial notions about "big government" intrusions into private lives, Conservative messaging on the census issue was "blinding Canadians to truths they need to know about themselves," foolishly misapplying the "democratic safeguard" of suspicion to target "the single most valuable source of domestic data in a global information age."

Travers acknowledged that the census controversy raised issues of information control, and we might add that knowledge from census or other data is practically and institutionally produced, not self-revelatory (Fraser 1989; Green 2009). But the government's handling of the issue did not address such questions in any thoughtful way, nor support an effective democratization of information or of knowledge production. Even some conservative sympathizers noted contradictions in the handling of the census issue. William Robson (2010) argued that "prodigious growth" in the economic role of the state was rightly a matter of concern, but that, as government's reach grows, "so does the need for information with which citizens can hold them to account." In eliminating the MLFC, libertarians had "taken out the wrong target" and won the wrong fight, depriving "those who want government to do less but do it better" of indispensable information. 
Indeed, the government itself seems to have noticed the precipice on which it stood. The detailed agricultural census was retained as mandatory, while the 2011 short-form census was released to the accompaniment of an intensive barrage of advertising emphasizing its mandatory status. Aftershocks of the battle over the MLFC also continue to be felt when justifications for its elimination are perceived to clash with innovations in data gathering or monitoring in areas such as crime, security, or voter response-management.

\section{Neoliberalism's Challenge to Sociology}

Cancellation of the MLFC concretized several threats to the practice of sociology and the social sciences in general. At the most basic level, it undermined a key source of data, presenting a real problem for academics and researchers reliant on Statistics Canada. While social scientists may find other resources to mitigate the loss of this data, the decision underscores more substantial, long-term threats to academic practice, especially to the professional role of sociologists. Like other professionals, sociologists have a duty to inform the public on matters of general interest, even if it can fairly be argued that their zeal for doing so has sometimes varied. The decision to end the MLFC attacked not only the availability of data for sociological analysis, but questioned the credibility of sociologists to speak to public issues; representing their data as suspect and open to subjective interpretation, and sociologists themselves as a self-serving professional elite.

However, the neoliberal threat to sociology goes beyond these matters to the heart of the sociological vision. Sociology eschews the notion that individuals can be understood outside of social and historical contexts. From a sociological perspective, the individual is not alone even in the absence of others and does not make individual choices, or hold particular values or beliefs, outside of a social location. Noting Margaret Thatcher's famous statement that, "there is no such thing as society," Frances Fox Piven commented:

Although we were slow to recognize it, Thatcher and the neoliberal project she championed declared war on the basic tenets of the sociological enterprise. To be sure, we also study individuals and families, but the sociological enterprise rejects the radical individualism of Thatcher and the personal responsibility plank of the Republican "Contract with America." Our distinctive preoccupation is with the social environments that shape individual and family life. (Piven 2007:13-14; see also Piven 2011) 
Neoliberalism devalues the sociological vision, but in its radical populist forms, also threatens every discipline in the social sciences and humanities. The libertarian populist delegitimation of any rigorous form of social inquiry, whether statistical or not, which happens to contradict individualized personal experience or opinion or the political priorities of neoliberal governments, holds potentially deadly consequences for intellectual culture, for informed public policy, and for the ethical conduct of reasoned public debate about the future of social life. If there is a positive element to this situation, we may hope it lies in responses that will - ironically - foster common cause between adherents of divergent schools and tendencies in sociological theory, research, and political engagement.

Developing an effective common cause means sociologists must also take into account aspects of their own practice that make them targets. It is, to some degree, a fair criticism that policy-oriented sociology has sometimes neglected the concerns and perceptions of ordinary folk while drawing closer to those of agencies with funding to offer and institutional statuses to protect; or that it has spoken in a language more suited to technocrats than citizens. Conversely, however, even the emancipatory and critical impulse central to recent sociology can expose the discipline to danger. As Saurette notes of talk radio (2011:215), populist mobilizing strategies can colonize "emancipatory language and utopian aspirations," including the language and aspirations of politically committed sociologists who wish to honour the voices of ordinary folk and their situated knowledge, practices, and perspectives, or to examine critically the institutional practices by which power and knowledge are produced. Even sociologists' self-critical reflexivity could be misappropriated to discount evidence which conflicts with ideological or policy agendas, or to represent politically noncompliant researchers as speaking only from a particular, and discreditable, social location or subject position. We are not suggesting that sociologists stop being self-critical or emancipatory in their practice, but that they be prepared both for hostile criticism and for hostile appropriation.

Finally, though beyond the scope of this discussion, the Conservatives' efforts to "retreat" from governance by actively dismantling and delegitimating part of its machinery, while simultaneously strengthening prescriptive control in other areas of social life, begs a sociological rethink of the state. It has proven too easy for journalists (e.g., Potter 2010b) and even academics (e.g., Gordon 2010) to caricature critical sociology's suspicion of the state, and to shoehorn sociologists into "fer it" or "agin' it" boxes which do little justice to the actual positions of, say, Marx, Durkheim, Foucault, or a host of more recent others writing 
on "reinstitutionalization" of the state, on sovereignty and governance, on public duties of care, and on the public roles of professions (e.g., Evans et al. 1985; Wilson 2001; O'Neill 2005).

\section{Conclusion}

It will likely be a long time, if ever, before the process involved in the Conservative government's elimination of the MLFC is fully understood. Cabinet secrecy ensures that result. The gap in understanding may be filled with speculation on supposedly "real" reasons behind the decision. But it is important to distinguish between motivations and justifications. The government's justifications were situated in a distinctive ideological narrative, employed a characteristic rhetorical arsenal, and had a specific political direction: ideological in their references to individual and familial privacy and freedom from government coercion, rhetorical in their attempts to represent those using the census data as privileged special interests, and political in their characterization of defenders of the MLFC as members of "elites" whose legitimacy was inauthentic. These post hoc justifications do not give us the political calculus involved in the actual decisions concerning the MLFC, nor about subsequent governmental decisions affecting the work of Statistics Canada. Perhaps it was thought that the kind of data delivered by the MLFC would be used primarily to justify increased government spending, by agents not especially friendly to the Conservative political agenda. Our focus here has not been to specify the exact reasons or motivations; indeed, the actors themselves may not have had any firm understanding, merely gut ideas and beliefs. Instead, we have argued that these actions can be located in the discursive logic and rhetoric of a libertarian populist appeal commensurate with neoliberal conceptions of individualism, private property, and the agency of the state.

We have noted the threats the census decision poses for sociologists and social science researchers in general, regarding research, the authority of professionals to speak on matters of policy and public interest, and the premises underlying a sociological vision. Beyond the MLFC issue itself, we want to conclude with some larger questions for sociological theorization that the census incident poses; questions about the practical generation of knowledge and of claims to objectivity, integrity, and truth. Does the abolition of the MLFC, and opposition to that abolition, indicate a fundamental shift in the practices by which knowledge and truth claims are being generated? Or is there, rather, a discursive shift in how knowledge is evaluated and deployed? How does the state's (or at least, the governing party's) decision to eliminate a significant source of 
policy-relevant data square with current sociological notions of power and knowledge? What implications arise more broadly from this incident for sociological theories of class relations, organizational and communicative politics, institutionalization, and governance?

The decision to end the MLFC opens up a series of important questions for consideration, providing opportunities for renewed sociological reflection and debate. They are also questions which sociologists ignore to their peril.

\section{REFERENCES}

Bijsterveld, Karin. 2010. Acoustic cocooning: How the car became a place to unwind. The Senses and Society 5(2):189-211.

Boothby, Daniel and Torben Drewes. 2010. The Payoff: Returns to University, College and Trades Education in Canada, 1980 to 2005. e-brief, Education Papers. Toronto: C.D. Howe Institute, August 24.

Chase, Steven and Tavia Grant. 2010. Statistics Canada chief falls on sword over census. The Globe and Mail. Toronto, Ontario, July 21. Downloaded February 27, 2012. http://www.theglobeandmail.com/news/politics/sta$\underline{\text { tistics-canada-chief-falls-on-sword-over-census/article1647348/ }}$

Corrigan, Philip and Derek Sayer. 1985. The Great Arch: English State Formation as Cultural Revolution. Oxford: Blackwell.

Cosh, Colby. 2010. Census squabble: Weak arguments shouldn't have even worse foundations. Maclean's.ca, July 12. Downloaded February 27, 2012. http://www2.macleans.ca/2010/07/12/senseless-about-the-census/

Coven, Victoria. 2003. A history of statistics in the social sciences. Gateway: An Academic journal on the Web, Spring. http://grad.usask.ca/gateway/ art_Coven_spr_03.pdf. Accessed 26 February 2012.

Coyne, Andrew. 2010. How will they know how many boaters to harass? Maclean's.ca, July 8. Downloaded February 27, 2012. http://www2.macleans.ca/2010/07/08/how-will-they-know-how-many-boaters-to-harass/

Crawford, Matthew B. 2009. Shop Class as Soulcraft: An Inquiry into the Value of Work. New York: Penguin.

Curtis, Bruce. 2001. The Politics of Population: State Formation, Statistics, and the Census of Canada, 1840-1875. Toronto: University of Toronto Press. 2002. Foucault on governmentality and population: The impossible discovery. Canadian Journal of Sociology 27(4):505-533.

Desrosieres, Alain. 1991. How to make things which hold together: Social science, statistics and the state. Pp. 195-218 in P. Wagner, B. Wittrock, and R. Whitley, eds., Discourses on Society: The Shaping of the Social Science Disciplines. Dordrecht: Kluwer. 
Dillon, Lisa. 2010. The value of the long form Canadian census for long term national and international research. Canadian Public Policy 36(3):389-93.

Evans, Peter B., Dietrich Rueschemeyer, and Theda Skocpol. 1985. Bringing the State Back In. Cambridge: Cambridge University Press.

Ewen, Stuart. 1976. Captains of Consciousness: Advertising and the Social Roots of the Consumer Culture. New York: McGraw-Hill.

Fiske, John and John Hartley. 1978. Reading Television. London: Methuen.

Flanagan, Thomas. 2009a. Waiting for the Wave: The Reform Party and the Conservative Movement. Montreal and Kingston: McGill-Queen's University Press. 2009b. Harper's Team: Behind the Scenes in the Conservative Rise to Power. Kingston and Montreal: McGill-Queen's University Press.

Foucault, Michel. 2007. Security, Territory, Population. Trans. G. Burchell. Basingstoke: Palgrave Macmillan.

Fraser, Nancy. 1989. Unruly Practices: Power Discourse and Agenda in Contemporary Social Theory. Cambridge: Polity Press.

Gardner, Dan. 2010. A census designed by "drunken monkeys." The Ottawa Citizen, July 14. Downloaded February 27, 2012. http://www2.canada.com/ victoriatimescolonist/news/comment/story.html?id=98a5c8a3-548e4b9e-9cee-aa978e671579.

Gordon, Stephen. 2010. The census, evidence-based policy analysis and a reversal of roles. Worthwhile Canadian Initiative, August 25. Retrieved 05/05/2011 from http://worthwhile.typepad.com/worthwhile canadian initi/2010/08/the-census-evidencebased-policy-analysis-and-a-reversalof-roles.html

Grant, George. 1965. Lament for a Nation. Toronto: McClelland and Stewart.

Green, Bryan. 2009. Gerontology and the Construction of Old Age: A Study in Discourse Analysis. Piscataway, NJ: Aldine Transaction.

Green, David A. and Kevin Milligan. 2010. The importance of the long form census to Canada. Canadian Public Policy 36(3):384-88.

Habermas, Jürgen. 1975. Legitimation Crisis. Trans. T. McCarthy. Boston: Beacon Press.

1989 [1962] The Structural Transformation of the Public Sphere: An Inquiry into a Category of Bourgeois Society. Trans. T. Burger and F. Lawrence. Cambridge: Polity Press.

Hacking, Ian. 1990. The Taming of Chance. Cambridge: Cambridge University Press.

Harrison, Trevor. 1995. Of Passionate Intensity: Right-Wing Populism and the Reform Party of Canada. Toronto: University of Toronto Press.

Harvey, David. 2005. A Brief History of Neoliberalism. New York: Oxford University Press. 
Hofstadter, Richard. 1966. Anti-Intellectualism in American Life. New York: Vintage Books.

Jansen, Robert S. 2011. Populist mobilization: A new theoretical approach to populism. Sociological Theory 29(2):75-96.

Lethbridge Herald. 2010. Census no issue for commission. Lethbridge, AB, July $15, \mathrm{~B} 1$.

Kay, Jonathan. 2011. Among the Truthers. Toronto: HarperCollins.

Macpherson, Crawford Brough. 1962. The Political Theory of Possessive Individualism: From Hobbes to Locke. Oxford: Clarendon.

Manning, Preston. 1992. The New Canada. Toronto: Macmillan Canada.

Martin, Lawrence. 2011. Harperland: The Politics of Control. Updated. Toronto: Penguin.

Mirowski, Philip and Dieter Plehwe, eds. 2009. The Road from Mont Pèlerin: The Making of the Neoliberal Thought Collective. Cambridge, MA: Harvard University.

Noel, Sidney J.R. 1990. Patrons, Clients, Brokers: Ontario Society and Politics, 1791-1896. Toronto: University of Toronto Press.

O’Neill, John. 2005. Civic Capitalism: The State of Childhood. Toronto: University of Toronto Press.

Palmer, Bryan. 1979. A Culture in Conflict: Skilled Workers and Industrial Capitalism in Hamilton, Ontario, 1860-1914. Kingston and Montreal: McGill-Queen's University Press.

Piven, Frances Fox. 2007. The neoliberal challenge. Contexts 6(3):13-15.

2011. Crazy talk and American politics: or, my Glenn Beck story. The Chronicle of Higher Education: Chronicle Review, February 10. Retrieved 26 February 2012 from http://chronicle.com/article/CrazyTalkAmerican/126334/

Poovey, Mary. 1998. A History of the Modern Fact: Problems of Knowledge in the Sciences of Wealth and Society. Chicago: University of Chicago Press.

Potter, Andrew. 2010a. Sometimes a gaffe is more than a gaffe. Maclean's, July 26, p. 12.

2010b. The census: power, knowledge, and role-reversal. Maclean's. ca, August 25, retrieved 05/05/2011 from http://www2.macleans.ca/tag/ foucault/

Proudfoot, Shannon. 2010a. Tories agree to explain decision to scrap long-form census. Postmedia News, July 18.

2010b. Statistics council suggests compromise to end census battle. Postmedia News, July 26.

Radwanski, Adam. 2009. Stephen Harper: Anarchist? The Globe and Mail, Second Reading. Toronto, Ontario, July 13. Accessed 14 July 2011 at 
http://www.theglobeandmail.com/news/politics/second-reading/radwanski/stephenharperanarchist/article1216560/.

Ramp, William, and Kerry J. Badgley. 2009. "Blood money": Gambling and the formation of civic morality. Pp. 19-45 in J.F. Cosgrave and T.R. Klassen, eds., Casino State: Legalized Gambling in Canada. Toronto: University of Toronto Press.

Robson, William. 2010. Good information comes at a price. The Globe and Mail, Tuesday, July 13.

Rollison, David. 2006. The specter of the commonalty: Class struggle and the commonweal in England before the Atlantic world. The William and Mary Quarterly 63(2):221-252.

2010. A Commonwealth of the People: Popular Politics and England's Long Social Revolution, 1066-1649. Cambridge: Cambridge University Press.

Saurette, Paul. 2010. When smart people make stupid decisions. The Mark, July 23. Accessed 14 July 2011 at http://www.themarknews.com/ articles/1907-when-smart-parties-make-stupid-decisions

Saurette, Paul, and Shane Gunster. 2011. Ears wide shut: Epistemological populism, argutainment and Canadian conservative talk radio. Canadian Journal of Political Science 44:195-218.

Scott, Jonathan. 2004. What were commonwealth principles? The Historical Journal 47(3):591-613.

Sennett, Richard. 2006. The Culture of the New Capitalism. New Haven, CT: Yale University Press.

Simpson, Jeffrey. 2010. PM's census policy senseless but great for the party. Globe and Mail, July 17. Downloaded February 27, 2012. http://www. theglobeandmail.com/news/opinions/pms-census-policy-senseless-butgreat-for-the-party/article1642881/

Stiegler, Bernard. 2010. For a New Critique of Political Economy. Cambridge: Polity Press.

Thompson, Debra. 2010. The politics of the census: Lessons from abroad. Canadian Public Policy 36(3):378-82.

Travers, James. 2010. Census change latest move in PM's dumbing down of Canada. Toronto Star, July 8.

Valpy, Michael. 2010. Harper's census push months in the making. Globe and Mail, July 26.

Veall, Michael R. 2010. 2B or not 2B? What should have happened with the Canadian long form census? What should happen now? Canadian Public Policy 36(3):395-99. Downloaded February 27, 2012. http://www. theglobeandmail.com/news/politics/harpers-census-push-months-in-themaking/article1651526/

Veldhuis, Neil and Charles Lamman. 2010. Coming to our census. Views from the West. Winnipeg Free Press, July 23. 
Wernick, Andrew. 1991. Promotional Culture: Advertising, Ideology and Symbolic Expression. London: Sage.

Williamson, Vanessa, Theda Skocpol, and John Coggin. 2010. The Tea Party and the remaking of Republican conservatism. Accessed 12 July 2011 at http://static.sdu.dk/mediafiles//7/B/3/\%7B7B30B0ED-7AA0-4065952B-1FCAB8B161C9\%7DWilliamson\%20Skocpol\%20Coggin $\% 20$ Tea\%20Party.pdf

Wilson, H.T. 1977. The American Ideology. London: Routledge.

1989. Retreat from Governance: Canada and the Continental-international Challenge. Hull, QC: Voyageur.

2001. Bureaucratic Representation: Civil Servants and the Future of Capitalist Democracies. Leiden: Brill.

2002. Capitalism After Postmodernism: Neo-Conservatism, Legitimacy and the Theory of Public Capital. Leiden: Brill.

Yalnizyan, Armine. 2010. The anti-information information society, brought to you by the anti-government government. The Progressive Economics Forum, July 18. http://www.progressive-economics.ca/2010/07/18/ the-anti-information-information-society-brought-to-you-by-the-antigovernment-government/. Retrieved 26 February, 2012.

Trevor Harrison is a Professor of Sociology at the University of Lethbridge and Director of Parkland Institute at the University of Alberta. His research interests include political sociology, political economy, and public policy. His most recent book, Against Orthodoxy: Studies in Nationalism (co-edited with the late Dr. Slobodan Drakulic) was published by the University of British Columbia Press in 2011.

trevor.harrison@uleth.ca

William Ramp is an associate professor of sociology at the University of Lethbridge, a member of the Canadian Network of Durkheimian Studies, the Centre for Culture and Community Studies, and the Parkland Institute, and a research affiliate of the Prentice Institute for Global Population and Economy. His interests are in the cultural history of sovereignty, identity, religion, and the civic sphere. He is the author of a number of articles on Durkheimian and post-Durkheimian cultural sociology, including "Durkheim and after: Religion, culture, and politics," pp. 52-75 in B.S. Turner, ed., The New Blackwell Companion to the Sociology of Religion (Oxford: Blackwell).

ramp@uleth.ca 